Nepalese Journal of Biosciences 2: 158-159 (2012) Brief Communication

\title{
Impact of climate change on birds at Biratnagar and its surroundings
}

\author{
Kanchan Jha and Bharat Raj Subba \\ Department of Zoology, Post Graduate Campus, T.U., Bitarnagar, Nepal \\ E-mail: kanchanjha48@yahoo.com
}

Key words: Climate change, anthropogenic impacts, population of birds

Biratnagar sub-metropolis (Lat. $26^{\circ} 20^{\prime} \mathrm{N}$, Long $87^{\circ} 16^{\prime} \mathrm{E}$, Alt. $72 \mathrm{msl}$ ) is an industrial city situated in south east Nepal. Its south border is India. It is a major centre for trade and commerce with India. The climate is tropical and monsoonic. Herbaceous plants are dominant components of vegetation. Most of the trees present here are planted ones including Dalbergia sisso, Albizzia sp., Anthocephalus cadamba, Magnifera indica, Ficus religiosa, Fucus bengalensis, Litchi chinensis, Vitex negundo, Azadirachta indica, Zizyphus jujuba, Cassia fistula, Areca catechu, Eucalyptus citridora, Phyllanthus emblica, Coccus nucifera, Bombax ceiba etc. Among herbaceous species, dominant ones are Cynodon dactylon, Imperata cylindrica, Sacharum spontaneum, Chrysopogon aciculatus and Axonopus compressus. The main crops of Biratnagar are Oryza sativa, Zea mays and Triticum aestivum. Climate change and urbanization are slowly engulfing the ecologically fragile land of this city.

For the present study, data of maximum and minimum air temperatures for the years 1970 , 2004, 2007 and 2011 as well as data of rainfall for the years 2004 and 2011 were obtained from the Department of Hydrology and Meteorology, Dharan and a comparative study was done. Interviews with local people were taken about the impact of climate change on birds. Secondary data were collected through the review of published and unpublished documents, reports and internet facility.

The study of 1970, 2004, 2007 and 2011 metrological data of Biratnagar indicated some notable changes in the patterns of temperature and rainfall (Figs. 1-3)

Decrease in number of bird species from 115 to 81 has been reported earlier (Subba, 1995; Jha \& Subba, 2011). Due to increase in urbanization many suitable habitats of wetland birds have been either converted into agricultural land or settlement areas and existing wetlands are facing scarcity of water.

The impact of climate change on Nepalese birds is currently poorly understood, but is likely to be significant. Biratnagar is not an exceptional place from the global impact of climate change. The comparative study of meteorological data in the study indicates that there are some trends in climate change at Biratnagar too. In winter it is excessive cold and summer is very hot. Rainfall pattern has changed and the soil is drying up. Thrushes which were recorded in the years from 1994 to 1998 have left to turn out in winter since 1999 at Biratnagar.

Up to three decade back, at Biratnagar, bird's habitats were almost safe. Subba (1995) recorded 115 species of birds but Jha and Subba (2011) recorded only 81 species on regular observations. Many species like Leptoptilos dubius, Cicona episcopus, Gypus indicus, Gyps 
fulvus, Circus melanoleucos, Charadrius dubius, Tringa nebularia, Burhinus oedicnemus, Capella gallinago, Athene brama, Alcedo meninting, Megalaima haemacephala and Dendrocopus nanus did not turn out during present observation. This may be due to either habitat shrinkage/anthropogenic impacts or climate change. Within one decade urbanization has touched the peak here. Marshy lands have been encroached almost completely. River waters have become polluted and are not suitable for wetland birds. People are unwilling for the conservation of bird habitats and their nesting and feeding sites. The population of each and every species of bird has been declining markedly. If mitigation for climate change is not thought of and implemented in time, many of the migratory bird species will discontinue their regular visits to Biratnagar and surrounding areas in future. To save birds safeguard measures have to be made popular in time and people have to realize why birds have to be protected and conserved.

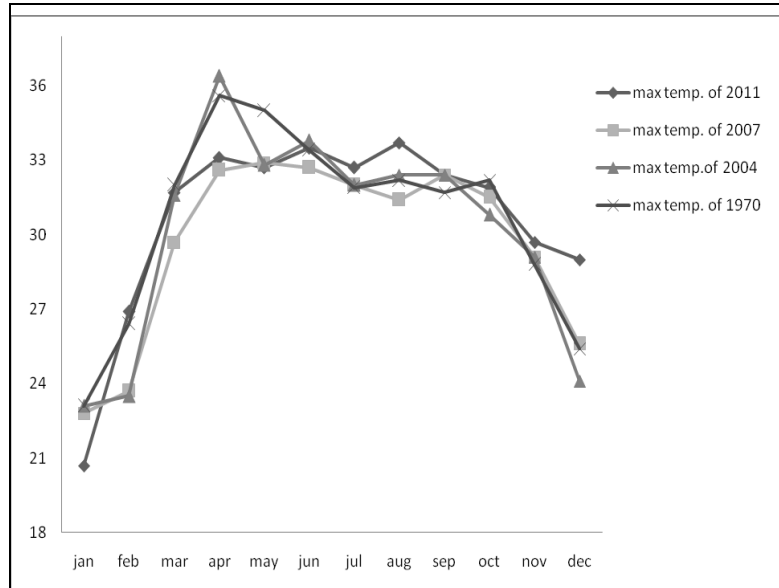

Figure 1. Variation in maximum air temperature at Biratnagar.

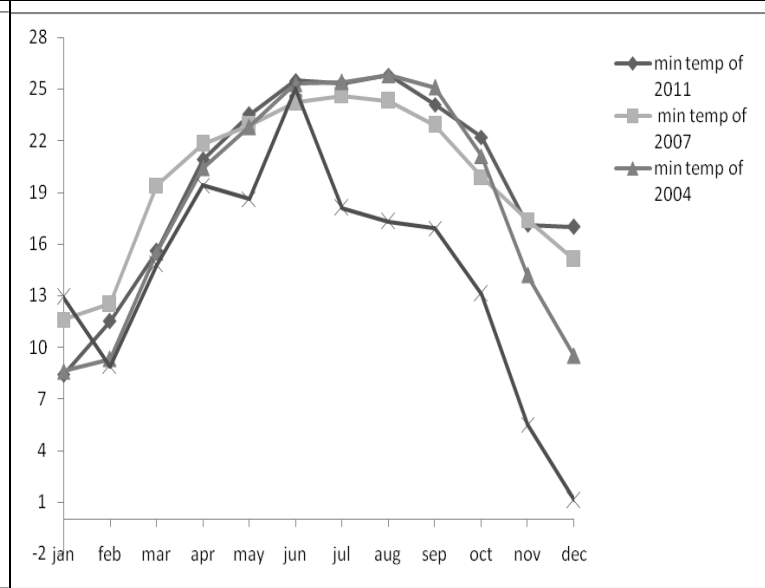

Figure 2. Variation in minimum air temperature at Biratnagar.

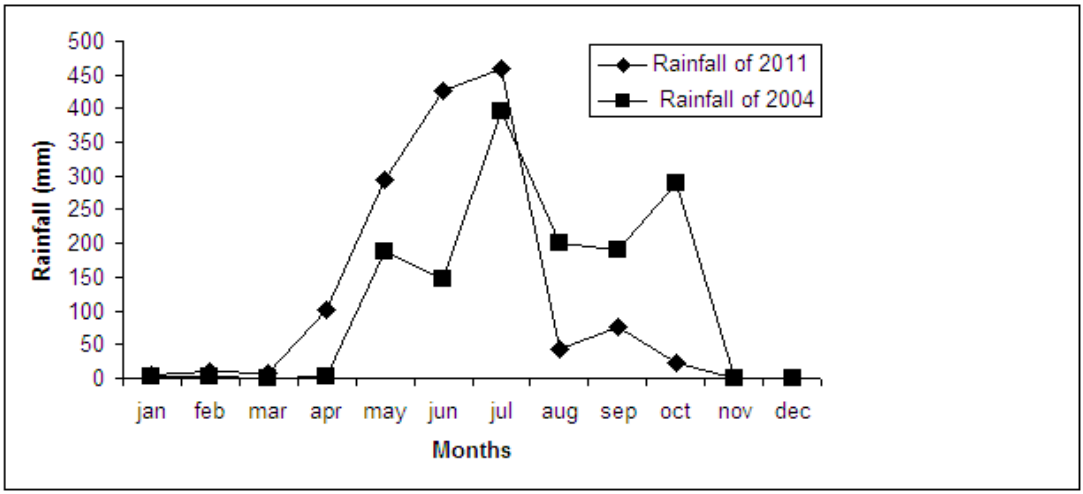

Figure 3. Variation in rainfall pattern at Biratnagar.

\section{References}

Jha, K. \& B.R. Subba. 2011. Studies on birds of Biratnagar Sub-Metropolis, Nepal. Nepalese Journal of Biosciences 1: 37-40.

Subba, B.R. 1995. Checklist of birds of Dharan, News letter for Birdwatchers. Published bimonthly by Sridhar at Navbharat Enterprises, Sesadripuram, Banglore. 560020 India, 34(4): 115-116. 